\title{
A Brand-New Method of Quantifying Lease Incremental Borrowing Rate under IFRS 16 and Topic 842
}

\author{
Francesco Bellandi ${ }^{1}$ \\ ${ }^{1}$ Head of Technical Accounting, Multinational, London, UK \\ Correspondence: Francesco Bellandi, Head of Technical Accounting, Multinational, London, UK. E-mail: \\ Francesco_bellandi@yahoo.com
}

Received: September 4, 2021

Accepted: October 6, 2021

Online Published: October 20, 2021

doi:10.5539/ijbm.v16n11p92

URL: https://doi.org/10.5539/ijbm.v16n11p92

\begin{abstract}
One of the most contentious issues of lessee's accounting under IFRS 16 and FASB ASC Topic 842 has been how to compute a lessee's incremental borrowing rate (hereafter, IBR). A proper quantification of IBR is important because it affects the amount of a lessee's right-of-use asset and lease liability recognized at lease commencement in the statement of financial position, as well as depreciation and interest expenses ongoing. Such a determination poses theoretical and practical difficulties to companies. This article develops a brand-new method that follows a conceptual approach that converge accounting and finance theory, to strike a balance between rigorous theory and practical application for companies. The proposed approach starts with a lessee's actual average borrowing rate and compares it with its theoretical average borrowing rate based on synthetic rating. It then flexes the average rate along the interest term curve and derives the monthly rates applicable to each monthly cash flow. It adjusts the rates based on each specific lease features as defined in the standards, periodically updates the specific lease interest rate curves, and computes a lease IBR as the internal rate of return of the cash flows discounted at the monthly specific rates applicable to that specific lease. It finally compares with benchmarks. The proposed model is innovative because it is framed within, and consistent with, the definition of incremental borrowing rate in those accounting pronouncements, uses three starting references cross-checking each other, includes both an internal perspective of a company's actual interest rates and an external market perspective, and is relatively easy to model in a partially automated spreadsheet application.
\end{abstract}

Keywords: Topic 842, IFRS 16, incremental borrowing rate, synthetic rating

\section{Introduction}

International Accounting Standards Board (IASB), (2020), IFRS 16, Leases and U.S. GAAP Financial Accounting Standards Board (FASB) (2021), FASB ASC Topic 842, Leases have come into effect lately. One of the most contentious issues has been how to compute a lessee's IBR.

A proper quantification of IBR is important because it affects the amount of a lessee's right-of-use asset and lease liability recognized at lease commencement in the statement of financial position, as well as depreciation (through the value of the right-of-use asset) and interest expenses ongoing.

The topic is still open to debate and deserves more academic research, because such a determination poses theoretical and practical difficulties to companies, which are better explained in the following paragraphs. In summary, most of the times, an IBR is not readily observable on the market or from accounting records. In fact, it is an entity-specific, lease-specific, driven by specific factors, incremental borrowing rate. Conversely, available evidence is sector- or sometimes company-wide, non-asset specific, not necessarily linked to the same drivers, and on an average basis. Being lease specific, the cost/benefit of IBR computation is key for companies that have several thousands of leases, and this deserves finding a precise but at the same affordable and user-friendly method.

The object of the study is a theoretical and methodological research that leads to an applied method of IBR computation that, on one hand, is fully compliant with applicable accounting standards and in line with modern finance theory and, on the other hand, can help solve the issues encountered in company practice.

This proposed method is brand new, even though has some aspects in common with previous work in the area, and the author has tested it in spreadsheet computations that have proved to be user-friendly to build and maintain.

The hypotheses of the study are the constraints and assumptions that IBR should follow based on the requirements 
in applicable standards, as explained below along the several steps of the model.

The theoretical implication of this article can be expanded to show how a company-wide average borrowing rate can be reasonably transformed in an asset-specific incremental borrowing rate (where, in this specific application, the asset is a lessee's right-of-use asset). The practical implication of the study is a tool that companies can easily replicate to achieve such an objective.

This paper is organized as follows. It first discusses the literature review on the topic, it then explains hypothesis and the research design, taking into consideration IFRS and U.S. GAAP key requirements and companies concerns about the complexity of determining a lessee's IBR, and finally it explains the new approach developed by the author.

\section{Literature Review}

An important stream of research in studying lessee's incremental borrowing rate is the treatment of credit risk in leases. Altamuro et al. (2014) analyze whether operating leases affects the way financial institutions evaluate credit risk associated with lending. They find that financial institutions adjust credit ratings for operating leases, especially when residual value guarantees are involved, or bankruptcy risk is high. Antrade et al. (2011) find a positive association between credit spreads in Credit Default Spread markets and noncancellable operating leases. Cotton et al. (2013) compare actual ratings with Damodaran (2009) synthetic rating method both unadjusted and adjusted for leases to find that leases affect actual ratings effected by credit agencies. These authors prefer synthetic credit rating to other methods based on multiple financial ratios, such as Blume et al. (1998) or Ayers et al. (2010), which have a potential of multicollinearity.

Another aspect of study that is germane to the topic of this article is how academics have determined discount rates to recast financial statements to show operating leases on balance sheet. For estimated lease assets and liabilities, Graham et al (1998) use a $10 \%$ rate to discount minimum lease payments of the next five year. Fitó et al. (2013) use a 10-year Treasury bond rate or other risk-free rate plus a spread commensurate to a company's credit quality. Rauh et al. (2012) discount lease payments committed beyond five years at zero-coupon yield of A-rated corporate debt. Pardo et al. (2015) employ discount rates used by the companies in pensions and other provisions. Graham and Lin (2018) use company specific average interest rate or, if zero or not available, the one of its SIC-code industry. Morales-Díaz et al. (2018a) analyze the different factors in the definition of IBR. They stress that interest rate curves should be regularly updated. They show two theoretical approaches, to derive IBR from zero-coupon interest rate curves for different maturities (i.e., discounting each period cash flow at the zero-coupon rate corresponding to that period) and yield curves (i.e., discounting all cash flows at a single rate corresponding to the maturity of the lease). As to credit risk, for an entity that does not issue quoted bonds and hence has no public ratings they suggest using either a theoretical credit rating by comparing financial ratios with comparable quoted entities or using recent financing obtained by the company.

A third aspect is what the relationship between collateralized borrowing and leases should be, considering that the new standards require to use an IBR on a collateralized basis. Leases are generally considered akin to collateralized debt to the extent they give lessor a right to repossess and priority in bankruptcy. In fact, according to Eisfeldt et al. (2009) leases are super-secure claims to be assimilated to secured borrowings. Leasing would even have higher debt capacity than secured lending because of easier repossession procedures. Morales-Díaz et al. (2018b) adjusts interest rate curves for collateral by applying spread percentage changes of quoted CDS, determined as the change that would maintain the same probability of default, keeping sensitivity to basis point constant, when recovery rates are changed. However, Binfarè et al (2021) find that $20 \%$ of companies reporting under FASB (2021), FASB ASC Topic 842 has used lease discount rates that reflect unsecured debt.

As these contributions show, the determination of IBR is a complex subject that involves several technical aspects with theoretical and practical difficulties. This is confirmed by the standard-setters discussions explained in the following paragraph in acknowledging companies' difficulties. Therefore, devising a practical as well as theoretically correct computation of IBR is, to a certain extent, still a puzzle for academics and practitioners.

\section{Research Approach and Links to Theory}

Key hypotheses of this article come from the definitions of IBR in IASB (2020), IFRS 16, Para. and FASB (2021), FASB ASC 842-10-20: the fact that IBR is lessee specific, lease specific, an incremental rate, and reflecting certain features described in the standards. These definitions are threefold. First, IBR is a lessee's borrowing rate, that is, company specific (as such, also reflecting lessee's creditworthiness), not a threshold that can be taken from the marketplace as is. Second, it is an incremental rate, not an average rate as an overall company rate may be. Third, they define IBR not in terms of a rate applicable to an overall entity (a lessee), but at each specific lease level. They draw an analogy between IBR and the interest rate of a borrowing under similar conditions. The concept of 
IBR factors the specificity of a lease agreement in the features that an equivalent borrowing should reflect. This is in terms of amount similar to the value of the right-of-use asset (the definition in FASB (2021), FASB ASC 84210-20 refers to an amount equal to the lease payments), lease term, similar security (FASB (2021), FASB ASC 842-10-20 explicitly mentions borrowing on a collateralized basis), and similar economic environment. IASB (2020), IFRS 16, para. BC161 acknowledges that IBR also takes into account the creditworthiness of the lessee, and the nature and quality of collateral. The expression economic environment is undefined, although it would include jurisdiction and currency of borrowing. IFRS Interpretations Committee, IFRIC Update September 2019 noted that IASB (2020), IFRS 16 does not necessarily require to determine IBR based on a loan that has a similar payment profile to the lease, although this is consistent with the above definition given by the standard, especially if a rate that is readily observable from the market is used as a starting point.

A specific question is how a lessee can develop an approach that takes all these drivers into consideration. For example, for a lessee in a multiple of a thousand agreements, it would be like having to determine specific loan rates for several thousands of units of accounts. All this translates into the need for a model that could differentiate several thousand interest rates, possibly producing a continuous range of set of rates where management should select which one to see as appropriate for each specific lease.

Confronted with such a difficult situation, several companies have tried to simplify, sometimes using a single rate per quarter, or other approaches, which are clearly not compliant with the standard. IASB (2020), IFRS 16, para. BC162 explicitly states that, while a readily observable rate such as a property yield or the rate of a similar borrowing may be used as a starting point, it needs to be adjusted to determine a specific lease IBR.

Hypotheses on some alternative solutions can be derived from the standards themselves. In addressing companies concerns, under IASB (2020), IFRS 16, para. B1, FASB (2021), FASB ASC 842-20-55-20, and FASB (2016), ASU 2016-02, paras. BC121, BC201 a company may use a portfolio approach to determine the discount rate. This is allowed provided that a company does not reasonably expect that the effects of grouping leases with similar characteristics differ materially from an application on a lease basis. However, this is a very limited alternative solution because the portfolio approach is somehow circular, as an assessment of materiality at individual lease level would anyway require a detailed calculation. FASB (2016), ASU 2016-02, para. BC201 and FASB (2021), FASB ASC 842-20-55-20 also consider that under certain circumstances where a parent company's credit standing influences the lease pricing, a subsidiary may use a parent or group's IBR, such as when a group treasury manages the subsidiary's funds, or the parent guarantees a subsidiary's payments to a lessor. U.S. GAAP only (FASB, 2016, ASU 2016-02, paras. BC406-BC407) has a practical expedient for private companies to use a risk-free rate determined at lease commencement for a period comparable to the lease term (the portfolio approach is also applicable to this accommodation). Finally, upon initial adoption of IASB (2020), IFRS 16 only, when based on the modified retrospective method, a lessee may elect to apply a single discount rate to a portfolio of lease with reasonably similar characteristics (IASB (2020), IFRS 16, para. C10.a). These simplifications are valid only upon transition, not exempting a company from a full determination of IBR subsequently. However, as subsequent determination of IBR is limited to new leases and certain modifications and reassessments, it may reduce initial implementation efforts and costs.

All the above shows the importance of the research question about how to define a method that is theoretically robust and at the same time practical and inexpensive to use to determine IBRs for a company with thousands of leases.

This article follows a conceptual approach that converge accounting and finance theory, to strike a balance between rigorous theory and practical application for companies. It is explained in the form of procedural steps that a company should adopt to implement this method. However, as any accounting and management system, it eventually relies on professional judgment to devise the appropriate application to a specific company that reflects its facts and circumstances.

The approach proposed has some features in common with some of the methods that have described in the abovementioned literature, namely Damodaran (2009) synthetic rating and interest rate curves. However, this method is innovative for four reasons. First, it is framed within, and consistent with, the definition of incremental borrowing rate in IASB (2020), IFRS 16 and FASB (2021), FASB ASC Topic 842. Second, it does not use a single method but three approaches cross-checking each other. Third, it does not simply start from an external perspective of market rates, but it conjuncts it with an internal perspective of a company's actual interest rates. Finally, the author has proved that it is relatively easy to create a partially automated spreadsheet application of the method (not presented here) that also has a relatively easy maintenance.

\section{Results and Discussion}




\section{First Step: Lessee's Actual Average Borrowing Rate}

A first point in the definition of IBR is that it must be lessee specific. Therefore, the proposed method starts from the computation of a rate that is applicable to the lessee entity. In the case of a big-ticket lease, the specific borrowing that would be otherwise negotiated would be considered. Where this is not the case, the general debt funding the entity would be used as an alternative to leases (equity sources should be ignored for the purpose of determining IBR). General debt would typically reflect the average mix of sources of funds used by the entity. Even when a specific financing is used for a big-ticket project, this would ordinarily not cover its full amount as it would be based on a loan-to-value ratio, the remainder of it to be funded by the average general debt sources of the entity. Therefore, in most cases, a lessee would have to compute an overall company rate that reflects the mix of its borrowing sources and its current facts and circumstances, including its creditworthiness. IASB (2020), IFRS 16 does not define the term 'borrowing cost', but IAS 23, para. 5 (although in the context of capitalization of borrowing costs) includes interest and other costs incurred in connection with borrowing, which means that all types of debt related fees should be factored in. Under FASB ASC 835-20-20, issue costs on debt are also included for the purpose of capitalized interest costs for obligations with explicit interest rates.

Hence, as a starting point, an average rate is determined based on actual financial statements, computed as borrowing costs/average interest-bearing debt. It may happen that the company has a plan for raising additional borrowing, not specific to the lease, by the time the lease will commence. In such a situation the forthcoming loan would also be taken into consideration to project what the average borrowing rate would be after including that loan.

\section{Second Step: Lessee's Theoretical Average Borrowing Rate}

The benefit of an average rate derived from the financial statements in Step One above is that it is an actual rate, reflecting all actual events and circumstances applicable to the company. Another perspective is to seek what a theoretical rate would be for that company. This proposed approach uses Damodaran (2009) synthetic ratings. If the entity has not issued listed debt and has no credit rating by rating agencies, this is a quite simple way to compute what rating the company would have if it were listed and approached the external public market for funding. Based on tables for different sizes of companies, which are regularly updated and available on the Internet, ratings can be associated to different levels of interest coverage ratio (Earnings before Interest and Taxes - EBIT)/interest expenses). In those tables, each rating has a spread from risk free rate associated. Therefore, the applicable interest rate would be obtained by adding the spread that corresponds to the entity interest covering ratio to the free-risk rate. However, as the rate is still an average rate at company level, the risk-free rate to consider is the one corresponding to the average term of the overall interest-bearing debt of the company. Here, different levels of sophistication can be used to compute the term of each debt source and then the average term at company level, from using average time to maturity to Macaulay duration, i.e., the weighted average time to maturity of debt, where the weights are the present values of the debt's cash flows divided the amount paid for the debt. In defining interest expenses, under the proposed method there should be consistency with the chosen accounting definition of borrowing costs, as explained above.

There may be alternative ways of deriving a starting point of corporate debt average interest rate that might be considered as a normative base. For example, an entity that knows its weighted average cost of capital (WACC) can use its formula to compute a fully levered WACC. Unlike the company average borrowing rate determined from actual financial statements (an accounting-derived measure), this would come from a market quantification by using market values of debt. The section on literature review has mentioned other methods.

The use of a theoretical or normative rate in conjunction with the actual rate in Step One above gives more robustness. It also provides management with some hints to understand what the difference between the two rates is and discuss why, as well as understand the potential zone where average rates may be acceptable, considering both actual data and normative data. Management may then make an educated judgment on the most sensible positioning of the starting point within the band, such as an average of the two methods or any other justified conclusion.

Step One and Step Two do not consider alternative methods based on readily available market rates such as corporate yields or property yields, because the proposed method intends to start from a rate that is specific to the company. These sorts of market-based comparable will be used later as benchmark testing.

\section{Third Step: Flexing Along the Interest Term Curve}

The actual and theoretical rates obtained so far are average rates at company level reflecting the actual mix of source of debt and related lengths. The next step is to transform such rates to rate curves for that specific company 
along the time dimension. To consider the dimension of time, a risk-free interest rate curve for nominal loan, which can be downloaded from a country national bank or from financial institutions, shows the risk-free rate applicable to each future month for example up to the next 40 years. A similar curve can be constructed for company's overall average rates by positioning the company's actual average rate defined in Step One at its average term (if in a graph, in the $\mathrm{X}$ axis). By then applying the same percentage changes at each monthly interval as in the risk-free rate interest rate curve, the pattern of the risk-free rate will be replicated to the company's actual rate. Although these are still average spot rates for that company, they are now flexed to consider the time dimension. This implicitly assumes that the entity's characteristics in terms of mix of sources of debt, credit standing, etc. are maintained but adjusted for length of time of funding. A similar curve can also be constructed for synthetic rating, by adding the identified spread applicable to the company to the risk-free rate interest rate curve. This implicitly assumes that the spread does not change by having a longer length of debt, assumption that might be modified by adjusting spread for different time periods.

\section{Four Step: Moving from Rates at Company Level to Rates at Lease Level}

The previous steps have created two curves of company's average interest rates, actual and theoretical, flexed along time, from which management may exercise professional judgment on where to position. As known in finance theory, the use of a single yield-to-maturity as a discount rate is an inferior method to a set of rates, each one for each payment modelled after the interest rate curve and reflecting the cash flow profile and risk of a specific financial instrument. Each lease has its own length and cash flow profile in terms of dates and amounts of payment on those dates. The sum of each payment (monthly, quarterly, annually, as the case may be) discounted by the rates that correspond to those specific lengths will create a total discounted cash flow specific to that lease. In other terms, this approach discounts each payment at its applicable rate, not at a single rate as if a comparable corporate yield were used.

At this stage, the interest rate curve is company-specific, but still at overall company level, not at lease level. To transform the curve at lease level, all the factors in the IASB (2020), IFRS 16 and FASB (2021), FASB ASC Topic 842 definition of IBR, not only time, should be considered. A way to do this is to envisage a set of adjusting hurdles to be added or subtracted to the entire curve to reflect, separately, different factors. A first factor is the value of the right-of-use asset of the specific lease (in absolute terms or relatively to the total size con the lease portfolio of the company). Other factors comprise lease types as a proxy for security (e.g., the business risk and repossession features of an office may be different from a commercial store, vehicles, or technology apparatus that depends on intangible operations), and economic environment. The interest rate curve adjusted for the combination of hurdles related to the lease classification to which a lease belongs will create rates that are specific to that lease. Of course, some judgment is involved here, so it is important that the hurdles are directionally correct, discussed and justified, and conservatively not too sensitive.

Once each lease payment in a series is discounted at its own rate, the sum of all discounted cash flow will be the present value of the lease. Its internal rate of return will be the single rate that makes that present value (obtained by applying the series of rates applicable to the series of payments) equal to the discounting of all cash flows at that single rate. In other terms, this will be the yield-to-maturity of the specific lease, and it will correspond to the IBR under IASB (2020), IFRS 16, paras. 26, 37 and FASB (2021), FASB ASC 842-20-35-1, i.e., a constant periodic rate of interest on the remaining balance of the lease liability that will then be used to compute the lease interest expenses throughout the term of the lease.

\section{Fifth Step: Moving to Incremental Rates}

The above computations incorporate future-looking curves of free-interest rates, past and current information about the company based on the latest financial statements, or theoretical rates that the current situation would predict normatively. Conversely, IBR is an incremental rate, that is, what the rate would be if a specific incremental lease is undertaken. Ideally, after each new lease, the company average rate changes. A big-ticket lease may really affect the company's average borrowing rate, and therefore a new computation will be needed for subsequent leases. For other leases, a single computation may be valid for a period until a series of new leases significantly modify the average rate. In practice, this means that the computation of the starting point should be kept updated along interim financial statements, possibly at least monthly, as well as after each big-ticket lease. Update of the interest rate curves should also be periodical. As to synthetic rating, each recalculation of interest coverage ratio should consider both EBIT and interest expenses after leases entered into in the prior periods.

\section{Sixth Step: Checking with Benchmarks}

After the computation, a sense check on benchmark data, such as corporate bond yields and property yields, may be appropriate. These methods are proposed as benchmarks and not alternative methods because they do not adhere 
to the IBR definition in the standards. It should be kept in mind that these are in effect benchmarks of the interest rate implicit in the lease. Under IASB (2020), IFRS 16, paras. 26, 41,45 and FASB (2021), FASB ASC 842-1020 , a lessee must use an IBR when the interest rate implicit in the lease is not readily determinable. Conversely, under IASB (2020), IFRS 16, para. C8, IBR is also required upon first adoption of the standard under the modified retrospective method. Property yields would be expected to be a cap in the range of interest rate implicit in a lease, because they would refer to the underlying asset, where the life of the right-of-use asset would generally be no longer than the underlying asset. IBR would also be expected to be below implicit rates, considering that for servicing debt repayment a borrowing rate would be expected to be lower than property yields. However, property yields do not refer to a specific property that may be leased and to the specific lessee company. Corporate bond yields consider country and related economic environment risk, but they refer to a company different from the lessee (including a different credit risk) and do not reflect any lease specific features. In addition, bonds are generally unsecured, while lease is secured by the lease asset. Finally, as bonds are marketable, their yields reflect a much lower liquidity premium than would be adequate to leases. They are generally held to represent a floor in the range of a lease implicit rates.

\section{Conclusion}

The method developed in this article translates a company-wide, non-asset specific, not necessarily linked to lease drivers, average borrowing rate into an entity-specific, lease-specific, driven by specific lease factors, incremental borrowing rate. The pros of this method are several. It is conceived to adhere with the definitions and requirements in IBR in IASB (2020), IFRS 16 and FASB (2021), FASB ASC Topic 842. It is thought to enhance robustness of analysis because it does not use a single methodology but three approaches cross-checking each other. It starts with entity-specific measures and not generically-applicable market rates. It permits the exercise of professional judgment within ranges gathered by objective evidence, and it allows a partial automation in a spreadsheet application that is relatively easy to develop and maintain. There are no specific restrictions to the use of this method, as it could be generalized to assets other than a lessee's right-of-use asset.

\section{References}

Altamuro, J., Johnston, R., Pandit, S. \& Zhang, H. (2014). Operating Leases and Credit Assessments. Contemporary Accounting Research, 32(2), 551-580. https://doi.org/10.1111/1911-3846.12033

Andrade, S. C., Henry, E., \& Nanda, D. (2014). The Impact of Operating Leases and Purchase Obligations on Credit Market Prices. University of Miami. http://dx.doi.org/10.2139/ssrn.1941896

Ayers, B. C., LaPlante, S. K., \& McGuire, S. T. (2010). Credit Ratings and Taxes: The Effect of Book-Tax Differences on Ratings Changes. Contemporary Accounting Research, 27(2), 359-402, https://doi.org/10.1111/j.1911-3846.2010.01011.x

Binfarè, M., Connolly, R. A., Grigoris, F., \& Liu, C. H. (2021). A New Lease on Firm Behavior. http://dx.doi.org/10.2139/ssrn.3672699

Blume, M. E., Lim, F., \& MacKinlay, A. C. (1998). The Declining Credit Quality of US Corporate Debt: Myth or Reality? Journal of Finance, 53(4), 1389-1413. https://doi.org/10.1111/0022-1082.00057

Cotten, B., Schneider, D. K., \& McCarthy, M. G. (2013). Capitalization of Operating Leases and Credit Ratings, Journal of Applied Research in Accounting and Finance, 8(1). Retrieved from https://ssrn.com/abstract=2276766

Damodaran, A. (2009). Leases, Debt and Value. Journal of Applied Research in Accounting and Finance, 4(1), 329. Retrieved from https://ssrn.com/abstract $=1435166$

Eisfeldt, A. L., \& Rampini, A. A. (2009). Leasing, Ability to Repossess, and Debt Capacity. Review of Financial Studies, 22(4), 1621-1657. https://doi.org/10.1093/rfs/hhn026

Financial Accounting Standards Board. (2021). FASB Accounting Standards Codification (FASB ASC), Retrieved

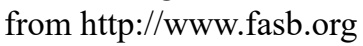

Financial Accounting Standards Board. (2016). Accounting Standards Update No. 2016-02. Leases (Topic 842) (ASU 2016-02). Retrieved from http://www.fasb.org

Fitó, M. A., Mota, S., \& Orgaz, N. (2013). Considering the Effects of Operating Lease Capitalization on Key Financial Ratios, Spanish Journal of Finance and Accounting. 42(159), 341-369. https://doi.org/10.1080/02102412.2013.10779750

Graham, J. R., Lemmon, M. L., \& Schallheim, J. S. (1998). Debt, Leases, Taxes, and the Endogeneity of Corporate 
Tax Status. Journal of Finance, 53(1), 131-162. https://doi.org/10.1111/0022-1082.55404

Graham, R. C., \& Lin, KC. (2018). How Will the New Lease Accounting Standard Affect the Relevance of Lease Asset Accounting? Advances in Accounting, 42, 83-95. https://doi.org/10.1016/j.adiac.2018.07.004

IFRS Interpretations Committee. (2021). IFRIC Updates. Retrieved from http://www.ifrs.org

International Accounting Standards Board. (2020). International Financial Reporting Standard 16. Leases - as amended (IFRS 16). Retrieved from http://www.ifrs.org

Morales-Díaz, J., \& Zamora-Ramírez, C. (2018a). IFRS 16 (Leases) Implementation: Impact of Entities' Decisions on Financial Statements, AESTIMATIO, The IEB International Journal of Finance, 17, 60-97. https://doi.org/10.5605/IEB.17.4

Morales-Díaz, J., \& Zamora-Ramírez, C. (2018b). Effects of IFRS 16 on Key Financial Ratios of Spanish Companies, Studies of Applied Economics, 36(2), 385-406. https://doi.org/10.25115/eea.v36i2.2536

Pardo Pérez, F., Giner Inchausti, B., \& Cancho Ortega, R. (2015). Operating Leases: An Analysis of the Economic Reasons and the Impact of Capitalization on Ibex 35 Companies. Retrieved from http://www.aeca1.org/pub/on_line/comunicaciones_xviiicongresoaeca/cd/55a.pdf

Rauh, J. D., \& Sufi, A. (2012). Explaining Corporate Capital Structure: Product Markets, Leases, and Asset Similarity. Review of Finance, 16(1), 115-155. https://doi.org/10.1093/rof/rfr023

\section{Copyrights}

Copyright for this article is retained by the author(s), with first publication rights granted to the journal.

This is an open-access article distributed under the terms and conditions of the Creative Commons Attribution license (http://creativecommons.org/licenses/by/4.0/). 